\title{
Caretaker Committee and Performance of Local Government Council in Anambra State
}

\author{
Joyce Mbaebie \\ http://dx.doi./org/10.4314/ujah.v21i4.1
}

\begin{abstract}
The study focused on the caretaker committee and performance of local Government Council in Nigeria: A study of Anambra State 2008 - 2013. In Nigeria federal structure, the three levels of government have legislative responsibility for various services and functions. The fourth schedule of the constitution outlines the functions and responsibilities of local government. The objective of the study is to: determine if the imposition of the caretaker committee system is a constitutional provision of the local government system in Nigeria especially Anambra State; to determine if the adoption of the caretaker committee by the state government affected the capacity of local government to perform its functions. The theoretical framework adopted focused on structural functional theory propounded by Gabriel Almond and J.S. Coleman in 1960. The study adopted descriptive research design and relied heavily on both primary and secondary data. Questionnaire was the major instrument for data collection and data were analyzed by the use of mean. Based on the data analysis, the following findings were made: the imposition of the caretaker committee system by state government to local governments is unconstitutional, the adoption of the caretaker committee by state government endangered the local government system capacity to perform its constitutional function. The study recommended amongst others that the use of or appointment of local government caretaker committee should be condemned, caretaker committee should be made to spend only three months to allow for a constitutionally elected local government executive.
\end{abstract}


Keywords: Local Government, Caretaker, Committee, Grassroots, Performance.

\section{Introduction}

\section{Background of the Study}

Local government is the third tier of government in Nigeria. It is created to perform the social, economic and political functions at the grassroots. It is also established to provide developmental services to the local people (Ekeh, 2005:1). Local Government administration in Nigeria is as old as colonial administration. During the colonial period, local administration was vested on officers appointed by the colonial administrators, the crown office, its later successors and then the regional governors. These appointees were called the district officers, "D.Os", for short, who were vested with legislative, executive and sometimes judicial functions. Each region had its own local government system quite different from other. Expectedly, there were as many systems of local government administration as there were regions and later states, which were subject to the whims and caprices of the system, their legal existence and operations.

In 1976, the Federal Government felt the necessity to reform local government administration. The result of the reform may be aptly described as the inception of modern local government administration in Nigeria. The general mood of the time called for a local government system that could serve not only as a machinery for even and accelerated development and democratic processes at the grassroots, but also provide the foundation for stability of the national political system. Brigadier Shehu M. Yar'Adua (Federal Government of Nigeria, 1976) impressively summarized the main objectives of the reforms when he stated:

... the federal military government was essentially motivated by the necessity to stabilize and rationalize government at the local level. This must, of necessity, entail the decentralization 
of some significant functions of the state government to local levels in order to harness local resources for rapid development. The Federal Military Government has, therefore, decided to recognise local governments as the third tier of governmental activity in the nation. Local Government should do precisely what the word government implies i.e governing at the grassroots or local level

The highlights of the 1976 local government reform were that it created a unified and uniform system of local government throughout Nigeria for the first time. The reform made deliberate efforts to set up a local government structure aimed at bringing government nearer to the people, thereby giving them the opportunity to participate in the administration of their areas.

In spite of this, the administration of this tier since independence has followed a pattern dictated by the whims and caprices of the state governments. The resultant effect of this relationship is the low rate of development in the local governments despite the fact that the basic idea for establishing the local government is to bring government and development nearer to the people. But, it is unfortunate that this objective has not been achieved in spite of the constitutional / legal provisions on the creation of the local government in Nigeria. The ideas of the 1979 constitutional provisions on local government should be in consonance with the prevailing dominant thoughts and moods of the populace expressed by the ruling groups. The reasons that informed reformation of the then nascent Local Government Administration in 1976 as encapsulated in the then Brigadier Yar'Adua's address euphemistically formed the background for the 1979 constitutional provisions on local government. The ordinary laws, decrees and edicts under military regimes fill in the gaps such as detailed regulations governing the functioning of the local government (Okoli and Okoli, 1990). 
Section 7(1) and sub-section (2) (a \& b) of 1979 constitution, states "the system of local government by democratically elected local government councils is under this constitution guaranteed; and accordingly, the government of every state shall ensure their existence under a law which provides for the establishment, structure, composition, finance and functions of such councils" (The Constitution, 1979). In the same vein Edict No 9 of 1976 A.S.N. Parts II, III 5.5 and 6 part IV and part V are on local government areas, alteration of area of authority, establishment of local governments, local government headquarters and compositions of councils and elections (Anambra State Government, 1976).

Section 7 (1) of 1979 Constitution basically gave two important aspects of the 1976 reforms guaranteed by its provisions. First, it sought to preserve the political character of the local government councils as representative bodies in the first few lines of this section. The constitution went further than the 1976 reforms did by not leaving room for nominated members as the local government law of all the states. Inspite of the constitutional provision on the establishment of local government councils they have been anything but democratic from 1979. Dissolution of council and dismissal of elected councillors by state governors and more the federal government and their replacement with care-taker or management committees of the constitutions were in for reckless abuse. Secondly, the remaining part of 5.7 (1) and 5.7 (b) of 1979 constitution has witnessed the trend that is completely opposite. The states violated the constitution with regard to the creation of new local government councils with reckless abandon,

Local government functions were spelt out in part IX, 5.54 and 55 of local Government Edict No 9 of A.S.N 1976 (Anambra State Government 1976). The objectives of the reforms as they concern functions received constitutional mandate in the $4^{\text {th }}$ schedule of the 1979 constitution. Section $1(\mathrm{~A}-\mathrm{H})$ of $4^{\text {th }}$ schedule contains 
functions that are exclusively the main responsibility of a local government council, while section $2(\mathrm{~A}-\mathrm{D})$ are on the functions that the local government concurrently perform with the state governments (The constitution, 1979: 119 - 120).

The question then is whether local government councils in Nigeria have been effectively empowered by constitutional and other legal provisions to perform these functions as provided by them and in the interest of the populace?

Local governments have failed to adequately perform their functions inspite of the constitutional and legal provisions that are aimed at enhancing their performance. Several factors are responsible for this, local governments in Nigeria face the serious obstacle of reconciliation with the competing power exercised by higher tiers of government that still handle them as lower or subordinate tier in most cases. In addition to local matters which the federal and state tiers may be constitutionally required to avoid, there are situations in which, there is preference of local government control even though the matters are capable of general power exercised by the higher tiers.

Though there was a constitutional and legal provision on the creation of local government in Nigeria but certain action and powers of the state has rendered them crippled and dependent on other tiers of government. Thus incapacitating their ability to perform and live up to expectation. This in essence has raised opinions that questioned the continued existence of Local Government Councils as a tier of government in general.

Irrespective of the much acclaimed commitment to local government as a distinct tier of government, this level of government has suffered from a number of debilitating blows which has painted it much more as an agent rather than a tier of government. For instance, as Davies (1998) and Okafor (2004) observed, the state governments on a number of occasions before 1987, and the presidency since 1987, have removed chairmen of Local Governments and even dissolved 
elected local government councils and appointed Administrators or caretaker committee in their place. As a result of such development, the local communities in which the appointed or nominated central government officials operated were invariably denied the basic right of either electing or choosing their leaders in whichever way they deemed fit. Besides, the loyalty of the appointed officials was inevitably bound to be to the appointing central government and not the beneficiary local communities. In the same vein, when leaders become centrally imposed the way sole Administrators and Caretaker Committees are appointed in Nigeria, accountability is jeopardized as support for and identification with the local government and its activities become difficult to muster. The implication is that participatory democracy at the grassroots becomes elusive. It is therefore the aim of this study to find answers to the following research questions.

\section{Research Questions}

1. Has the performance of the caretaker committee be seen to have outweighed that of a constitutionally constituted Local Government administrative system in Anambra State?

2. To what extent has the Caretaker Committee system impeded the autonomy of local government system in Anambra State?

3. Is there a dialectical relationship between autonomy and accountability in the Local Government System?

4. How has the adoption of the Caretaker Committee system by the state government affected the capacity of Local Government to perform its functions?

\section{Scope of the Study}

The study focused on the caretaker committee and performance of local government in Anambra State. The study is limited to three local government councils selected from the three senatorial zones in 
Anambra State such as Idemili North, Onitsha South and Orumba South Local Government Councils. The period covered by the study is 2003-2014. The reason for selecting this period was because it was purely guided by the caretaker committee in Anambra State of Nigeria.

\section{Conceptual Clarifications}

\section{Local Government}

The concept of local government involves a philosophical commitment to democratic participation in the governing process at the grassroots level. This implies legal and administrative decentralization of authority, power and personnel by a higher level of government to a community with a will of its own, performing specific functions as within the wider national framework. A local government is, at the grassroots level of administration meant for meeting the peculiar needs of the people (Agagu, 1997:18). Appadorai (1975:287) sees local government as government by the popularly elected bodies charged with administrative and executive duties in matters concerning the inhabitants of a particular district or place.

Local or grassroots government may be defined as having been established by law to perform specific functions within defined areas. A complex nation like Nigeria, with its many ethnic groups within a divergent and diverse culture, requires a high degree of decentralization, which they accomplish by creating local government authorities. Looking at the existence and relevance of local government, Ayo (2005) believes that local government is a territorial non-sovereign community possessing the right level of necessity organization to regulate its own affairs. Local government can be viewed as a legal personality with sufficient but limited powers of control over its staff, finance and funds (Amao, 2002). 
Ovwasa (2004) defined it as a subdivision of a nation (unitary country) and state (federal system) which has substantial authority to extract labour and impose tax over its jurisdiction. The council of such local government is constituted by law, and membership is either elected or selected. Ovwasa summarized the definitions of local government with the following observations:

i. Local government is created by law

ii. It has a representative government

iii. It is a lower level of government and it has a legal personality with the power to impose taxes in its areas of jurisdiction or competence, but with limited autonomy.

Local government at least in principle deals with grassroot politics, i.e., keeping law and order, basic sanitation, constructing and maintaining local roads, supplying water, administering local schools, for residents, et cetera.

\section{Caretaker Committee System}

Historically, the caretaker committee system of local government has no place in the constitution of the Federal Republic of Nigeria. However, its practice is dated as far back as the Nigeria's second republic. Ogunna (1996) noted that during the second Republic in all the states of the Federation, local governments were run by caretaker committee System consisting of loyalists appointed by state governors. Since after its first practice in the second Republic, the idea of managing the local governments with the caretaker committees has been on the increase in Nigeria. Between 2003-2013, out of the 36 states in Nigeria, 25 states have the local government administered by the caretaker committees (Okafor and Orjinta, 2013).

Apparently, this increase is as a result of the Lacuna created by the 1999 constitution as amended. The constitution did not specify the term of an elected Local Government council. The governors then capitalized on these loopholes and turned the Local Governments into 
an avenue of settling their loyalists. Section 7(1) of the 1999 constitution states thus;

The system of the Local Government by democratically elected government council is under this constitution guaranteed, and accordingly, the government of every state should subject to section of this constitution ensure their existence under a law which provides for the establishment, structure, composition, finance and function of such councils".

Similarly, the section 1(2) also states that;

The Federal Republic of Nigeria shall not be governed, nor shall any person or group of persons take control of the government of Nigeria or any part thereof except in accordance with the provisions of this constitution". Subsection 3 of the constitution emphatically summarized it by stating it inter-alia; "If any other law is inconsistent with the provisions of this constitution, this constitution shall prevent, and that other law shall to the extent of inconsistency be void.

Notwithstanding, the un-constitutionalism of the Caretaker Committees, what is worrisome however, is the reason many State Government has resorted to this practice as a panacea to rural development in Nigeria. We believe that in a democracy, leaders should be a product of the choice of the people but that is not the case in this circumstance.

Abbas and Ahmad (2012) emphasized that the situation has gotten so embarrassing that even where elections have been conducted, governors may deliberately force the tenures of Local Government chairman to lapse early, so as to pave way for the committees to work towards delivering their local government votes to the ruling party at any point in time thereby for disenfranchising the people.

Okafor and Orjinta (2013) supported the above and maintained that the nature of party politics played by the state 
governors at the local government level in order to maintain power violates democratic principles. This he said hinders the government from performing their functions, thereby destroying effective performance and development from its base.

Also Aluko (2010) argues that a serious point against nominated committees of management particularly in a civilian regime is that the government in power may misuse the system to keep its supporters indefinitely in control of local government. This is to frustrate the opposition parties and use the interregnum to strengthen its party organization at the grassroots through patronage which is provided by local governments in the form of contracts, job orders, junior staff appointments and promotions and such appointments touch sensitive positions.

Despite the foregoing, caretaker committee system is seen as way in which a sitting government especially a state government selects and appoints individuals in most cases of the same political parties, to manage the affairs of the local government.

Caretaker committee system to some people is a corrupt practice in its totality, to others it's antithetical to constitutional provision and to that extent should not be encouraged in any form and to a few persons; it is good because it has helped the leading parties in various states to keep their strength at the local units intact.

\section{Caretaker Committee System and Performance of Local Government in Anambra State, 2003-2014}

Historically, the general elections of 2003 in Nigeria ended the tenures of the second democratic transition in Nigeria from $1999-$ 2003. The 2003 general elections were massively rigged in all the states in Nigeria including Anambra. Dr. Chris Ngige who became the favoured candidate, managed the affairs of the state from 2003 2006, until he was removed from the office by the federal court of Appeal Enugu, having lost at the election Tribunal. Dr. Chris Ngige 
within the three years he spent in office never conducted local government election and that continued up till the period Mr. Peter Obi came on board on March 7th, 2006.

The era of Gov. Obi continued in the same way up to the end of his first tenure in the year 2010. During the administration of Peter Obi as the Governor of Anambra, within the period under review, the Head of service in all the 21 local government areas in Anambra were used by the state government to manage the affairs of the local government thereby denying the people the right to participate in their own local governance. This therefore not only politicized the civil servants but negatively impacted on the lives of the rural dwellers as no meaningful developmental projects were executed within the period. The local government funds were mismanaged by these officers. Sometimes contracts will be awarded but will not be executed while the contract fund was shared between the minority and the council officials. In the second tenure he made a lot of promises to conduct election in the local government which was never fulfilled up till the penultimate of his second tenure when he conducted a flanked local government election since 2003 on the $6^{\text {th }}$ February, 2014. This was because the election was not only massively rigged but results were announced even where election did not take place. Thus, the local government in Anambra has passed through numerous caretaker committee regimes.

This literature therefore would examine the travails of local governments, in Anambra state local government's systems under the following implications:

- Political effects

- Economic effects

- Social effects

Political Effects: Jega (2006) clearly emphasized that one of the basic constitutive elements of democratic governance is that of 
representation. Representation according to him is the people having freedom to choose by themselves who represents or governs them in leadership through a free and fair election. Under the caretaker committee leadership, the case is usually a dominance of the leading political party. In fact, from 2003 to 2014 it was not on record at any time when a governor appoints a member of an opposition party within the state as a member of caretaker committee.

To such leading political parties, the party is growing stronger and waxing their political popularity and acceptance at the grass root, while throwing away the real reason of basic dividend of democratic governance and effective performance of the local government by allowing a participatory leadership where even a minority would have a say.

On the other hand, it has been discovered that the committees only pay allegiance to the political class and had weaken the democratic structures and performance at local level in Anambra state from 2003-2014. While writing on "the challenges of Democratic governance in the fourth Republic in Nigerian; Ogbnnaya et al (2012) emphasized that the weakness of democratic institution at the local level is a challenge to democratic governance and effective performance of the local council. They referred to the institution as the executive, judiciary, the legislature. But of obvious fact is the reality that these institution can only function effectively in an elected democratic structure especially at the local government level, which caretaker committee appointment do not encourage, this is also a negation of the provision of the 1999 constitution of Nigeria as amended which provides for a democratically elected government at the grass root level which will encourage citizen participation.

Economic Effect: Unarguable is the fact the caretaker committees are not elected and therefore the prerequisite institution that could serve as checks and balances are non-existence, the members therefore see 
it as an avenue to loot the local government and enrich themselves with the public founds.

The empirical study of Okafor and Orjinta (2010); specifically in Onitsha North local" government areas revealed that there is a unanimous agreement on the lack of impact of caretaker committees on improving the living condition in the area. The committee members lamented that they only receive salary at the end of the month which is paid only when the governor approves it. From 2003 to 2014, local governments in Anambra State have not witnessed any serious economic development. The colossal failure of the committees gears to the fact that they are at the mercy of the state government. In most cases they are being referred to as watch dogs. For example in Ayamelum Local Government which consists of eight communities, the communities never witnessed any project done by the local government between this period under review and that is applicable to the rest of the local governments in the state.

Social Effects: The social implication has to do with the quality of relationship that exists between the caretaker committee members and the career civil servants even the people at large. However, the relationship has been that of "master-servant" relationship with the reason not farfetched. Since they merely represent the presence of the governor at the local government level, they are seen as 'semi gods' due to the fact that whatever happens, their godfather would come to their rescue.

It was discovered that from 2003 to 2014, the local government do not have any social contact with the masses. Evidence is the fact that no meaningful project was executed and commissioned by any caretaker committee regime. The underlying fact is that it hinders effective performance of local government and negates egalitarian society which is one of the constitutive elements of democratic governance according to Jega (2006). He expressed 
egalitarian society as a constitutive element of democratic governance. To him, it encourages constitutional regime, fairness, economic and social justice.

Therefore, the sustenance of local government administration on the basis of caretaker committees is apparently responsible for the weak democratic ethos and perennial underdevelopment of the local government in Anambra State, 2003 - 2014.

\section{Constitutional/Legal Basis of Local Government (Administration)}

Specifically, a constitution is a set of rights, powers and procedures regulating the structures of, and relationships among the public authorities and the citizens. A constitution defines the rules of political game. It lays down the laws that govern the governors. A (written) constitution contains carefully selected legal rules embodied in a document which order and govern the government of a country e.g, the (1979) constitution of the federal republic of Nigeria, that document established the principal institutions of government that are deemed fit for the realization of the ideals of the constitution. The ideals of the 1979 constitution provisions on local government should be in consonance with the prevailing dominant thoughts and moods of the populace expressed by the ruling groups. For instance, the reasons that informed reformation of the local government administration in 1976 as encapsulated in the then Brigadier Yar'Adua's address euphemistically formed the background for the 1976 constitutional provisions on local government. The ordinary laws of land made by the legislature and interpreted by the law courts, i.e, organic laws, decrees and edicts under military requires full in the gaps such as detailed regulations governing the functioning of local government (Okoli and Okoli, 1990).

Section 7(1) and sub-section (2) (a \& b) of 1979 constitution, states " the system of local government by democratically elected local government councils is under this constitution guaranteed; and 
accordingly, the government of every state shall ensure their existence under a law which provides for the establishment, structure, composition, finance and functions of such councils" (the constitution, 1979). In the same vein Edict No.9 of 1976 A.S.N. parts II, III 5.5 and b, part IV and part V are on local government areas, alteration of areas of authority, establishment of local governments, local government headquarters and composition of councils and elections (Anambra State Government, 1976).

Section 7(1) constitution basically gave two important aspects of the 1976 reforms guaranteed by its provision. First, it sought to preserve the political character of the local government council as representative bodies in the first few lines of this section. The constitution went further than the 1976 reforms did by not leaving room for nominated members as the local government law of all the states. Inspite of the constitutional provision on the establishment of local government councils they have been anything but democratic from 1979 till date. Dissolution of councils and dismissal of elected councilors by the state governors and more recently, the federal government and their replacement with care-taker or management committees have been the order of the day. These developments were signals or warnings that the guarantees of the constitution were in for reckless abuse. The state violated the constitution with regard to the creation of new local government with reckless abandon.

Although the constitution did not expressly or impliedly prevent the appointment of caretaker committee system, procedurally it can be imputed that the state actions in this regard were wrong and therefore a violation of a very vital legal process necessary for the creation of local government councils. Their actions were ultra vires (beyond state powers) and the creation of caretaker committee system was null and void and rightly wound up. 


\section{Autonomy and Accountability in Local Government System}

The clamour for autonomy by the local governments in Nigeria must be seen within this context. The issue seems to me to be clear-cut. The is not so much on whether local government should be more or less autonomous but instead and perhaps more importantly to whom or which level of government (state or federal) must local governments be accountable?

All over the world, local governments are accountable to the state governments in a federation or the central / national government in a unitary government. To make local governments accountable to the federal government in a federation makes local governments' parallel competitors with the state governments (Okoli, 1990). Such a situation will not only be clumsy, it will also detract from the statewide implementation of integrated programmes at the local government level.

The general practice in all federations however, is to subordinate local governments to the state governments. However, given the nature of our political culture, political integration and tolerance, such a course of action emasculates local governments especially those controlled by an opposing political party to the one controlling the state government. In conclusion, therefore, the issue is not so much the extent of autonomy as to the location of accountability. This is the challenge of the future for local government administration in Nigeria. In order to understand and appreciate fully the nature of magnitude and direction of the challenge, it is necessary to understand the authority, structure and functioning of local government in Nigeria. And to do this, an analysis of Decree No 15: Local Government (Basic Constitutional and Transitional Provisions) Decree, 1989 is imperatives. This is because the operations of local governments in Nigeria are predicated on that decree and its subsequent amendments. 


\section{Functions of the Local Government Administration}

Campbell (1988:9) identified the following as the possible roles of the local government;

1. A service agency

2. The local agent of stability, law and order

3. An extension of the central government

4. An agent of development

5. Combination of any of the above

Within the framework work of these roles, the main functions of the local government council as specified in the fourth schedule (section 7) of 1979 and 1999 constitution are as follows:

1a. the consideration and making of recommendations to a state commission on economic planning for any similar body on:

i. the economic development of the state, particularly in so far as the areas of authority of the council and of the state are affected;

ii. Proposal made by the said commission or body.

b. Collection of rates, radio and television licenses

c. Establishment and maintenance of cemeteries, burial grounds and homes for the destitute, or the infirm.

d. Licensing of the bicycles, trucks, (other than mechanically propel trucks) canoes, wheel-barrows and carts.

e. Establishment, maintenance and regulation of markets, motor parks and public conveniences.

f. Construction and maintenance of roads, streets, drains and other public high ways, parks, open spaces or such public facilities as may be prescribed from time to time of the House of Assemble by the State.

g. Naming of roads and streets and numbering of houses

h. Provision and maintenance of public conveniences and refuse disposal

i. Registration of all births, deaths and marriages. 
j. Assessment of privately owned houses or tenements for the purpose of levying such rate as may be prescribed by the House of Assembly of the State and;

k. Control and regulation of ;

i. Outdoor advertising and hoarding

ii. movement and keeping of pets of all description

iii. shops and kiosks

iv. Restaurants and other places for sell of food to the public and

v. Laundries.

2 The functions also include the participation of such council in the government of the state with respect to the following matters;

a. the provision and maintenance of primary education $\backslash$

b. the development of agriculture and natural resources, other than exploitation of minerals

c. the provision and maintenance of health services and

d. such other functions as may be conferred on a local government council by the House of Assembly of the State (Federal Republic of Nigeria 1979:119 - 120).

\section{Theoretical Framework}

In the analysis of the phenomena under study and in consideration of their nature, it is deemed necessary and suitable to adopt structural functional theory for this analysis. Like the systems analysis, structural functional analysis is also based on the concept of political system. This model of political analysis has been more widely used in the sphere of comparative politics because it provides for standard categories for different types of political system. It originated in the writings of Rad Cliff Brown and B. Malinowski. Then it was developed in the field of sociology by Talcott Parsons, Robert Merton and Marion Levy. Gabriel Almond and his associates developed it into a tool of political analysis. 
Gabriel Almond and J.S Coleman (The politics of the Developing Areas, 1960) identified four characteristics of the political system.

a. All political systems have political structures

b. The same functions are performed in all political systems with different frequencies and by different kinds of structures.

c. All political structures are multi-functional and

d. All political systems are mixed systems in the cultural sense, i.e they are based in a culture which is always a mixed of the modern and the traditional.

This approach was further development by Gabriel Almond and G.B. Powell comparative politics. A Developmental Approach (1966), Almond and his associates argued that all political systems, regardless of their type, must perform a specific set of tasks if they are to remain in existence as systems in working order, or in equilibrium, i.e as "ongoing system". These are the functional requirements of the system. With the assumption, they sought to modify David Easton's model of the political system, suggesting that inputs' and 'outputs' recognized by Easton can best be understood as 'functions' or functional requisites of political system. They sought to redefine these inputs and outputs with a deeper understanding of political process and proceeded to identify various structures corresponding to these functions, in order to evolve a structural-functional framework. They conceded that in various political systems, these functions may be performed by different kinds of political structures and sometimes even by structures which are not overtly recognized as being primarily, 'political'.

According to Almond and his associates discerned four input functions and three output functions. Input functions are:

1. Political socialization and recruitment.

2. Interest articulation

3. Interest aggregation 


\section{Political communication}

\section{Output functions are}

5. Rule making

6. Rule-application

7. Rule-adjudication

Of all these, output functions correspond to conventional governmental functions which are performed by formal governmental organs, viz legislature (rule-making) executive (rule-application) and judiciary (rule-adjudication). Almond has paid special attention to input functions which are performed by non-governmental structures or institutions. Although all structures are multi-functional, yet some structures are especially suited for specific functions.

The relevance of the theory to this study is that the structural functional theory offers enough provision in understanding the nature of the political system and how demands from the environment made by individuals and group are made on the political system for action to satisfy interest and how the various structures of the system performed specific functions which will encourage political development.

Local government is a structure created by the constitution of the federal republic of Nigeria to perform certain functions which is grassroots mobilization and rural development. To perform these functions, certain constitutional provisions were made to enable them successful execute their functions. Assessing the performance of local government therefore provisions/ structures put in place to ensure delivery of the stated goals that is assessing the structure as well as the functions which it performs. In this case the caretaker committee is a structure created and adopted by the state government for local government administration. 


\section{Research Design}

Descriptive survey tries to study events in its natural setting without the researcher manipulating the dependent and independent variables (Churchman, 1968).

\section{Methods of Data Collection}

The study relied heavily on both primary and secondary data. Both methods become necessary considering the nature of the work understudy. In primary data collection, field work was employed. The questionnaire was the major research instrument used in gathering data for this study.

\section{Population of the Study}

Anambra State has twenty-one local government councils. The population of the study comprises all the people of Anambra State. Three (3) local government councils from the twenty-one local government councils were randomly selected from the senatorial constituencies. The categories of people used were staff or workers in the local government drawn from both sexes (male and female).

\section{Table 1: Local Governments/Constituencies Selected}

\begin{tabular}{|l|l|l|l|l|}
\hline S/N & Names & Male & Female & Total \\
\hline 1 & $\begin{array}{l}\text { Idemili North (Anambra Central } \\
\text { Constituencies }\end{array}$ & 86 & 515 & 601 \\
\hline 2 & $\begin{array}{l}\text { Onitsha South (Anambra North } \\
\text { Constituencies) }\end{array}$ & 107 & 371 & 478 \\
\hline 3 & $\begin{array}{l}\text { Orumba South (Anambra South } \\
\text { Constituencies) }\end{array}$ & 67 & 210 & 277 \\
\hline
\end{tabular}

Source: From the Local Government Headquarters

The total population of workers in these local governments is one thousand three hundred and fifty-six (1356) workers/staff. Idemili 
North is made up of ten (10) localities namely Obosi, Nkpor, Ogidi, Eziowelle, Abatete, Uke, Umuoji, Ideani, Oraukwu, Abacha. Onitsha South comprises three localities namely Fegge, Odoakpu and part of Woliwo Layout while Orumba south is made up of Umunze, Ufuma, Owerri Ezukala, etc.

\section{Sample Size Determination and Sampling Technique}

Given the population of about one thousand three hundred and fiftysix (1356) workers/staff in the three local government councils in Anambra State, the sample size using Taro Yamani's formular was determined.

$$
\mathrm{n}=\frac{N}{1+N_{(\varepsilon)^{2}}}
$$

Where $\mathrm{n}=$ Relevant population sought

$\mathrm{N}=$ Total number of the three local government areas chosen for the study

$\mathrm{e}=$ Sampling error $(5 \%)$ in this case

The sample size is thus computed

$$
\begin{aligned}
& \mathrm{n}=\frac{\mathrm{N}}{1+\mathrm{N}(5 \%)^{2}} \\
& \mathrm{n}=\frac{N}{1+N_{(\Xi)^{2}}} \\
& \mathrm{n}=\frac{1356}{1+1356(5 \%)^{2}} \\
& \mathrm{n}=1+\frac{1356}{1356 \times 0.0025)} \\
& \mathrm{n}=\frac{1356}{1+3.39}
\end{aligned}
$$




$$
\begin{aligned}
& \mathrm{n}=\frac{1356}{4.39} \\
& \mathrm{n}=308.883 \\
& \mathrm{n}=309
\end{aligned}
$$

The sample size allocated to each L.G. is determined as follows

$$
\begin{array}{rrr}
\text { DNLG }= & 601 \times \underline{309} & =137 \\
\text { OSLG }= & 478 \times \frac{309}{1356}=109
\end{array}
$$

Orumba South $=277 \times \underline{309}$

$$
1356=63
$$

The sample size therefore is three hundred and nine (309)

\section{Method of Data Analysis}

The data collected was analyzed using appropriate statistical measures as follows: Arithmetic mean was used for research questions.

\section{Empirical Verification/Discussion of Major Issues in the Subject} Matter

The data collected by the use of questionnaire were organized and represented in tables below, for answering the respective research questions.

Table 2: Has the performance of the caretaker committee be seen to have outweighed that of a constitutionally constituted local government administration in Anambra State. 


\begin{tabular}{|c|c|c|c|c|c|c|c|}
\hline $\mathrm{S} / \mathrm{N}$ & Items & $\begin{array}{l}\text { SA } \\
4\end{array}$ & $\begin{array}{l}\text { A } \\
3\end{array}$ & $\begin{array}{l}\mathrm{D} \\
2\end{array}$ & $\begin{array}{l}\text { SD } \\
1 \\
\end{array}$ & $\bar{X}$ & Remaks \\
\hline 1 & $\begin{array}{l}\text { Caretaker committee } \\
\text { system has efficiently } \\
\text { functioned and } \\
\text { performed better than } \\
\text { elected local } \\
\text { government } \\
\text { administration }\end{array}$ & 19 & 10 & 200 & 80 & 1.8 & Rejected \\
\hline 2 & $\begin{array}{l}\text { The caretaker } \\
\text { committee system has } \\
\text { judiciously managed } \\
\text { the resources entrusted } \\
\text { to them than the } \\
\text { elected local } \\
\text { government } \\
\text { administration in } \\
\text { Anambra State. }\end{array}$ & 20 & 18 & 193 & 78 & 1.9 & Rejected \\
\hline 3 & $\begin{array}{l}\text { Local government } \\
\text { council can be said to } \\
\text { be well disposed } \\
\text { towards performing } \\
\text { their service functions } \\
\text { than the caretaker } \\
\text { committee system. }\end{array}$ & $\begin{array}{l}10 \\
0\end{array}$ & $\begin{array}{l}10 \\
1\end{array}$ & 60 & 48 & 2.8 & Accepted \\
\hline 4 & $\begin{array}{l}\text { The provision and } \\
\text { maintenance of } \\
\text { markets and motor- } \\
\text { parks received } \\
\text { adequate attention by } \\
\text { the caretaker } \\
\text { committee } \\
\text { administration than the }\end{array}$ & 10 & 41 & 58 & 200 & 1.5 & Rejected \\
\hline
\end{tabular}



Anambra State

\begin{tabular}{|l|l|l|l|l|l|l|l|}
\hline $\begin{array}{l}\text { elected local } \\
\text { government } \\
\text { administration. }\end{array}$ & & & & & & \\
\hline
\end{tabular}

Table 2 shows the mean of the responses from the respondents, serial number 1,2 and 4 were rejected by the respondents thus caretaker committee system has efficiently functioned and performed better than elected local government administration, the caretaker committee system has judiciously, managed the resources entrusted to them than the elected local government administration in Anambra State, the provision and maintenance of markets and motor-parks received adequate attention by the caretaker committee administration than the elected local government administration. On the other hand, serial number 3 was accepted by the respondents. Therefore, local government councils can be said to be well disposed towards performing their service functions than the caretaker committee systems.

\section{Table 3}

Responses on the extent to which caretaker committee system impeded the autonomy of local government system in Anambra State

\begin{tabular}{|l|l|l|l|l|l|l|l|}
\hline S/N & Items & $\begin{array}{l}\text { SA } \\
4\end{array}$ & $\begin{array}{l}\text { A } \\
3\end{array}$ & $\begin{array}{l}\text { D } \\
2\end{array}$ & $\begin{array}{l}\text { SD } \\
1\end{array}$ & $\bar{X}$ & Remark \\
\hline 1 & $\begin{array}{l}\text { The appointment of } \\
\text { caretaker committee in } \\
\text { the local government } \\
\text { councils suggest that } \\
\text { local government } \\
\text { autonomy is gradually } \\
\text { being whittled down. }\end{array}$ & 150 & 100 & 50 & 09 & 3.2 & Accepted \\
\hline 2 & $\begin{array}{l}\text { The implication for the } \\
\text { autonomy of local }\end{array}$ & & & & & & \\
\hline
\end{tabular}




\begin{tabular}{|c|c|c|c|c|c|c|c|}
\hline & $\begin{array}{l}\text { governments in Nigeria } \\
\text { has been that even } \\
\text { when central authorities } \\
\text { concede increased } \\
\text { autonomy to local } \\
\text { authorities, it is more } \\
\text { often directed } \\
\text { autonomy. }\end{array}$ & 140 & 110 & 40 & 19 & 3.2 & Accepted \\
\hline 3 & $\begin{array}{l}\text { Caretaker committee } \\
\text { system does not } \\
\text { promote local } \\
\text { autonomy. }\end{array}$ & 120 & 150 & 20 & 19 & 3.2 & Accepted \\
\hline 4 & $\begin{array}{l}\text { The caretaker } \\
\text { committee system } \\
\text { deepens the } \\
\text { dependency of local } \\
\text { governments on states, } \\
\text { thus leading to loss of } \\
\text { local initiatives to } \\
\text { authoritatively act on } \\
\text { development matters. }\end{array}$ & 130 & 120 & 30 & 28 & 3.1 & Accepted \\
\hline 5 & $\begin{array}{l}\text { The financial crisis in } \\
\text { the local government } \\
\text { has been worsened by } \\
\text { the adoption of the } \\
\text { caretaker committee. }\end{array}$ & 130 & 150 & 09 & 20 & 3.2 & Accepted \\
\hline 6 & $\begin{array}{l}\text { The adoption of the } \\
\text { caretaker committee } \\
\text { system has made the } \\
\text { local government } \\
\text { councils a mere } \\
\text { appendage of state } \\
\text { government. }\end{array}$ & 131 & 149 & 20 & 09 & 3.2 & Accepted \\
\hline
\end{tabular}


Table 3 shows the mean of the responses from the respondents. Table 2 sought information on the extent to which caretaker committee systems impede on the autonomy of local government as a third tier of government in Anambra State. Serial number $1-5$ were accepted by the respondents. Thus, the appointment of caretaker committee in the local government councils suggest that government autonomy is gradually being whittled down, the implication for the autonomy of local governments in Nigeria has been that even when central authorities concede increased autonomy to local authorities, it is more often directed, autonomy, caretaker committee system does not promote local autonomy, the caretaker committee system deepens the dependency of local governments on state, thus leading to loss of local initiative to authoritatively act on development matters, the financial crises in the local government has been worsened by the adoption of the caretaker committee system has made the local government councils a mere appendage of state government.

\section{Table 4: Responses on Dialectical relationship between autonomy and accountability in the local government}

\begin{tabular}{|l|l|l|l|l|l|l|l|}
\hline S/N & Items & $\begin{array}{l}\text { SA } \\
4\end{array}$ & $\begin{array}{l}\text { A } \\
3\end{array}$ & $\begin{array}{l}\text { D } \\
2\end{array}$ & $\begin{array}{l}\text { SD } \\
1\end{array}$ & $\bar{X}$ & Remark \\
\hline 1 & $\begin{array}{l}\text { Autonomy guarantees } \\
\text { accountability in the } \\
\text { local government } \\
\text { councils }\end{array}$ & 120 & 100 & 50 & 39 & 2.9 & Accepted \\
\hline 2 & $\begin{array}{l}\text { Undue interference in } \\
\text { the structure of local } \\
\text { government councils in } \\
\text { form of appointment of } \\
\text { caretaker committee } \\
\text { negates the principle of } \\
\text { accountability. }\end{array}$ & 20 & 160 & 17 & 12 & 3.2 & Accepted \\
\hline
\end{tabular}




\begin{tabular}{|l|l|l|l|l|l|l|l|}
\hline 3 & $\begin{array}{l}\text { The erosion of } \\
\text { autonomy in the local } \\
\text { government councils } \\
\text { weakens the ability of } \\
\text { local governments to } \\
\text { profitably discharge its } \\
\text { obligation to the public. }\end{array}$ & 130 & 100 & 50 & 29 & 3.0 & Accepted \\
\hline
\end{tabular}

Table 4 shows the mean of the responses from the respondents. Item 1 - 3 respectively were accepted by the respondents. Thus, autonomy guarantees accountability in the local government councils, undue interference in the structure of local government councils in form of appointment of caretaker committee negates the principle of accountability in the public sector, the erosion of autonomy in the local government councils weakens the ability of local governments to profitably discharge its obligation to the public.

Table 5: Responses on the adoption of the caretaker committee system by the state government affected the capacity of Local Government system to perform its functions

\begin{tabular}{|l|l|l|l|l|l|l|l|}
\hline S/N & Items & $\begin{array}{l}\text { SA } \\
4\end{array}$ & $\begin{array}{l}\text { A } \\
\text { I }\end{array}$ & $\begin{array}{l}\text { D } \\
2\end{array}$ & $\begin{array}{l}\text { SD } \\
1\end{array}$ & $\bar{X}$ & Remark \\
\hline 1 & $\begin{array}{l}\text { Caretaker committee } \\
\text { system results in an } \\
\text { untidy administrative } \\
\text { structures that has } \\
\text { affected the } \\
\text { performance of the } \\
\text { local government } \\
\text { councils. }\end{array}$ & 132 & 125 & 30 & 22 & 3.1 & Accepted \\
\hline 2 & $\begin{array}{l}\text { The intricate nature of } \\
\text { inter-governmental } \\
\text { relationship between }\end{array}$ & & & & & & \\
\hline
\end{tabular}


Mbaebie: Caretaker Committee and Performance of Local Government Council in Anambra State

\begin{tabular}{|c|c|c|c|c|c|c|c|}
\hline & $\begin{array}{l}\text { the local governments } \\
\text { and other tiers of } \\
\text { government is revealed } \\
\text { in an erosion of clearly } \\
\text { stipulated roles and } \\
\text { functions. }\end{array}$ & 125 & 128 & 40 & 16 & 3.1 & Accepted \\
\hline 3 & $\begin{array}{l}\text { Undue interference in } \\
\text { the leadership of local } \\
\text { government councils by } \\
\text { the state government } \\
\text { has negatively affected } \\
\text { the performance of } \\
\text { local government } \\
\text { councils. }\end{array}$ & 132 & 124 & 31 & 22 & 3.1 & Accepted \\
\hline 4 & $\begin{array}{l}\text { Caretaker committee } \\
\text { system erode the } \\
\text { functional competence } \\
\text { of local government } \\
\text { councils. }\end{array}$ & 130 & 100 & 50 & 29 & 3.0 & Accepted \\
\hline 5 & $\begin{array}{l}\text { The appointment of } \\
\text { caretaker committee } \\
\text { system by the state } \\
\text { governments deprive } \\
\text { local governments of } \\
\text { power to actually } \\
\text { perform their assigned } \\
\text { functions }\end{array}$ & 120 & 160 & 12 & 17 & 3.2 & Accepted \\
\hline 6 & $\begin{array}{l}\text { Development from } \\
\text { below cannot actively } \\
\text { be achieved if local } \\
\text { initiative of action is } \\
\text { lost to superior level of } \\
\text { government (state). }\end{array}$ & 160 & 110 & 22 & 17 & 3.2 & Accepted \\
\hline
\end{tabular}


Table 5 shows the mean of the responses from the respondents. Items $1-6$ were respectively accepted by the respondents. Thus, caretaker committee system results in an untidy administrative structures that has affected the performance of local government councils the intricate nature of inter governmental relationship between the local governments and other tiers of governments is revealed in an erosion of clearly stipulated roles and functions. Undue interference in the leadership of local government councils by the state government has negatively affected the performance of local government councils, caretaker committee erodes the functional competence of local government councils, the appointment of caretaker committee system by the state government deprive local government of power to actually perform their assigned functions and development from below cannot actually be achieved if local initiative of action is lost to superior level of government (state).

Based on the above responses of the people, it showed that the adoption of Caretaker Committee system by the state government for the local government imperil the local government system's capacity to perform its functions.

\section{Findings}

The findings in this study were summarized as follows:

- The imposition of the caretaker Committee system by the state government to local governments is unconstitutional.

- The performance of the caretaker committee system cannot be seen to have outweighed that of a constituted local government administrative system in Anambra State.

- Caretaker Committee system impeded on the autonomy of local government as a third tier of government.

- There is a dialectical relationship between autonomy and accountability. 
- The adoption of the Caretaker Committee by state government endangered the local government system capacity to perform its constitutional function.

\section{Conclusion}

In conclusion, the researcher posits that the constant use of Caretaker Committee by some state governments is fraudulent and has breached the aims and objectives for which they were meant to achieve. In view of this, therefore, the insistence of this by any state government should be legally treated by the Federal Government.

\section{Recommendations}

- The researcher recommends unequivocally and unreservably that the use of or appointment of local government Caretaker Committee should be condemned.

- The insistent of any state government on the appointment of Caretaker Committee should be legally disallowed by the Federal government.

- People at the grassroots should be constitutionally allowed to elect their representatives by themselves.

- Caretaker committee should be made to spend only three months to allow for a constitutionally elected local government executive.

\section{Joyce Mbaebie, PhD}

Department of Political Science

Nwafor Orizu College of Education, Nsugbe

Anambra State, Nigeria

joycembaebie.@gmail.com 


\section{References}

Abbas, B and Ahmad, B.M. (2012). "Challenges of democratization at the grassroots in Nigeria: Case study of Taraba state". Research on humanities and social sciences 2(7), http://www.iiste.org (accessed 20/5/15).

Agagu, A.A. (1997). "Local government: in Kolawole, D. (ed). Reading in political science. Ibadan: Dekaal.

Aluko, J.O. (2010). Local government elections and the challenges of democratic governance in Nigeria. Nigerian Newsworld, http//www.Nigeria

newsworld.com/articles/2010/111/htm/accessed (21/5/15).

Anambra State of Nigeria (1976). Edict No. 9. Of 1976. Enugu: Government printer.

Ananti, M.O; Onyekwelu, R.U and Madubueze, M.C. (2015). "Caretaker committee system and democratic governance in Nigeria's local government system: 2003 - 2014 in Anambra State" Global journal of management and business research vol. 15 (1) pp 33 - 37.

Appadorai, A. (1975). The substance of political. New Delhi: Oxford University Press.

Ayo, C. (2005). Local government as a vehicle of sustaining democratic setting. Kogi Affairs 4 (17).

Churchman, C.W. (1968). The system approach. New York: Dell Publishing Co. Inc.

Ekeh, C.C. (2005). Central Government's influence on local government autonomy in Nigeria: 1976 - 2004”. An unpublished M.Sc. thesis submitted to the department of Political and Administrative Studies of the University of Port Harcourt.

Federal Government of Nigeria (1976). Guideline to Local Government Reforms. 
Federal Republic of Nigeria (1979). The Constitution of the Federal Republic of Nigeria, Lagos.

Federal Republic of Nigeria (1999), Constitution of the Federal Republic of Nigeria, Lagos: Federal Government Press.

Ogbonnaya et al (2012). "The challenges of democratization governance in Nigeria's fourth republic of local governance in Nigeria: A historical approach". Nigerian Journal of Public administration and local government, 7 (11), 113 - 126.

Ogunna, A.E.C. (1996). Democratization of local government in Nigeria: A historical approach". Nigeria journal of public administration and local government. 7(1), 113- 126.

Okafor, J.C. \& Orjinta, I.H. (2013). Constitutional democracy and caretaker committee in Nigeria Local Government System: An Assessment" Commonwealth journal of local governance. http//www.epress.lib. uts. edu.au/ojs/index/php/cjig.

Okoli, E.F. and F.C. Okoli (1990). Foundations of government and politics. Onitsha: Africa FEP Publishers.

Ovwasa, O.L. (1995). Local Government Administration in Nigeria. Ibadan: Sunned Publishers. 